\title{
IMPROVEMENT TO THE PHYSICAL QUALITY AND IMBIBITION PATTERN IN SEEDS OF CANDEIA (Eremanthus incanus (Less.) Less.)
}

\author{
Antonio Cláudio Davide르, Olívia Alvina Oliveira Tonetti², Edvaldo Aparecido Amaral da Silva ${ }^{3}$
}

(received: June 14, 2010; accepted: April 28, 2011)

\begin{abstract}
The objective of this work was to develop a methodology for seed processing and X-ray analysis and to study imbibition pattern in seeds of candeia (Eremanthus incanus). Seeds were gathered in 2001 and 2002 in Morro do Pilar and Lavras respectively, processed and stored in a cold chamber $\left(5^{\circ} \mathrm{C} / 60 \% \mathrm{RH}\right)$ until the start of experiments. In order to identify unfilled seeds, a protocol was developed for X-ray use combining radiation energy (Kv) and exposure time (seconds). For elimination of unfilled seeds, an experiment was conducted using a South Dakota seed blower whereby different opening settings and ventilation times were combined. Original seed lots and categorized lots following radiograph viewing were tested by germination tests, with seeds being cleansed in sodium hypochlorite and scattered over blotting paper in 'gerboxes' and then taken to germinators with alternating temperatures of $20^{\circ}-30^{\circ} \mathrm{C}$ and 10 hours of light, for up to 15 days. Imbibition curves were determined under the conditions $30^{\circ} \mathrm{C}$, $20^{\circ}-30^{\circ} \mathrm{C} / 10$ hours of light and $30^{\circ}-20^{\circ} \mathrm{C} / 10$ hours of light. The X-ray protocol that best allowed viewing of internal seed structures was $30 \mathrm{Kv}$ for 45 seconds. Seed separation using the blower setting at a 3.0 opening for 30 seconds raised the number of embryonic seeds to values exceeding $99 \%$, also raising the germination rates as a consequence. The imbibition pattern is three-phased and the germination process is completed in 72 hours. Under alternate temperatures, primary root growth is favored.
\end{abstract}

Key words: Forest seeds, X-ray test, seed blower, unfilled seeds, germination.

\section{MELHORIA DA QUALIDADE FÍSICA E PADRÃO DE EMBEBIÇÃO DE SEMENTES DE CANDEIA (Eremanthus incanus (Less.) Less.)}

RESUMO: Conduziu-se este trabalho, com os objetivos de desenvolver métodos de beneficiamento e análise de raios $X$, e estudar o padrão de embebição de sementes de candeia (Eremanthus incanus). As sementes foram colhidas em 2001 e 2002, respectivamente, em Morro do Pilar e Lavras, beneficiadas e guardadas em câmara fria $\left(5^{\circ} \mathrm{C} / 60 \%\right.$ UR) até o início dos experimentos. Para identificar sementes vazias, foi desenvolvido um protocolo utilizando raios $X$ combinando potência de radiação e tempo de exposição. Para a eliminação das sementes vazias foi realizado um experimento utilizando soprador tipo South Dakota, combinando aberturas do aparelho e tempo de ventilação. Os lotes originais e as categorias encontradas pelas radiografias foram testadas por testes de germinação, no qual as sementes foram lavadas em hipoclorito de sódio e distribuídas sobre papel, em gerbox, levadas para germinadores com temperatura alternada $20-30^{\circ} \mathrm{C}$, com 10 horas de luz, por até 15 dias. Foram determinadas as curvas de embebição, nas condições de $30^{\circ} \mathrm{C}, 20-30^{\circ} \mathrm{C} / 10$ horas de luz e $30-20^{\circ} \mathrm{C} / 10$ horas de luz. O protocolo de raios X que melhor permitiu a visualização das estruturas internas da semente foi $30 \mathrm{Kv}$ por 45 segundos. A separação das sementes no soprador na abertura 3,0 por 30 segundos elevou o número de sementes com embrião para valores superiores a 99\%, tendo como consequência, a elevação das taxas de germinação. O padrão de embebição é trifásico e o processo de germinação se completa em 72 horas. Sob temperatura alternada, o crescimento da raiz primária é favorecido.

Palavras-chave: Sementes florestais, teste de raios $X$, soprador de sementes, sementes vazias, germinação.

\section{INTRODUCTION}

Also known as candeia, Eremanthus incanus is an arboreal species of family Asteraceae (CORREA, 1984), found in mountainous grasslands that extend from Bahia to Rio de Janeiro at an altitude range of $700 \mathrm{~m}$ to $1,200 \mathrm{~m}$ (NEMAF, 2003).

The interest for this species is chiefly economic and related to good quality wood, known for its resistance, durability and high energetic potential (CETEC, 1994). For this reason, candeia exploration has been on the increase and so has the demand for candeia seedlings, as a result, in order to foment new plantations. However, information about seed manipulation in this genus is yet scarce, and so far experience has often reported low germination rates (VELTEN; GARCIA, 2005; DAVIDE; TONETTI, 2003).

Causes for low quality seeds may include occurrence of sterile dispersing structures, often without

\footnotetext{
${ }^{1}$ Agronomic Engineer, Professor, DSc. in Forest Engineering - Departamento de Ciências Florestais, Universidade Federal de Lavras/UFLA Cx. P. 3037 - 37200-000 - Lavras, MG, Brasil - acdavide@dcf.ufla.br

${ }^{2}$ Forest Engineer, Ph.D. Candidate in Forest Engineering - Departamento de Ciências Florestais, Universidade Federal de Lavras/UFLA - Cx. P. 3037 37200-000 - Lavras, MG, Brasil - oaotonetti@dcf.ufla.br

${ }^{3}$ Agronomist, Professor PhD in Forest Seeds - Departamento de Produção Vegetal - Universidade Estadual Paulista Júlio de Mesquita Filho 18603-970 - Botucatu, SP, Brasil - amaraldasilva@fca.unesp.br
}

Cerne, Lavras, v. 17, n. 3, p. 321-326, jul./set. 2011 
embryo formation, as reported by Velten and Garcia (2005) in a study with the same species. However, removing such structures by air flowing equipment is indeed possible and has been already applied to seeds of Eremanthus erythropappus by Tonetti et al (2006). That said, if it is true that the quality of a seed lot is directly connected with the physical characteristics of its constituent units, identifying such structures becomes critical, noting that these can be quickly identified by using the X-ray technique which allows not only a quick assessment of the internal structures of the embryo but also the identification of some types of mechanical and insect-inflicted damage (SEED NEWS, 2001; SIMAK, 1991).

Along with the issue of physical quality in a seed lot, the next step is to understand seed requirements throughout the germination process. This process involves a chain of physiological events usually following a threephase imbibition pattern which culminates with protrusion of a primary root. This chain of events is influenced by several factors that include temperature and light presence. A daily fluctuation of temperature may also be required and is frequently observed in seeds of arboreal species, whether or not in connection with a light requirement, a common occurrence among species that colonize open areas (COPERLAND; MCDONALD, 1999), including Eremanthus incanus.

This work is therefore intended for the development of a methodology for seed processing and X-ray analysis, and for studying the imbibition pattern in seeds of Eremanthus incanus.

\section{MATERIAL AND METHODS}

\subsection{Seed origin and processing}

Seeds were gathered in 2001 and 2002 in the municipalities of Morro do Pilar and Lavras respectively. Processing was done with the use of sieves, and what was thought of as the seed is actually a dispersion unit known as achene. Seeds were maintained in a cold storage chamber $\left(5^{\circ} \mathrm{C} / 60 \% \mathrm{RH}\right)$, in semipermeable plastic bags until the start of experiments.

\subsection{Characterization of seed lots}

\subsubsection{Moisture test}

Once in the cold chamber, the moisture content was determined for the seed lots. Tests included 4 replicates of 0.5 grams per lot, using a forced air enclosed structure $\left(103^{\circ} \mathrm{C} / 17 \mathrm{~h}\right)$ (ISTA, 1993) and having aluminum foil as receptacle.

\subsubsection{Purity}

Seed purity determination was based on the definition proposed by a seed analysis standard known as Regras para Análise de Sementes (BRASIL, 1992), according to which, for dispersion structures of the 'achene' type, pure seeds are: (a) achenes and achene fractions more than half the original size, unless it is obvious that they contain no seeds; (b) seeds and seed fractions more than half the original size, with or without pericarp.

Two $1.4 \mathrm{~g}$ samples were analyzed in each lot and pure seeds were separated from other seeds and inert material. The result was given as percentage of pure seeds in the seed lot.

\subsubsection{Germination}

Seeds were washed in sodium hypochlorite at 2\% (2 minutes) and rinsed with distilled water. Samples were incubated in a Mangelsdorfii germinator at $20^{\circ}-30^{\circ} \mathrm{C}$, lit by four fluorescent daylight bulbs (20W) (10 hours of light at $30^{\circ} \mathrm{C}$ and 14 hours of dark at $20^{\circ} \mathrm{C}$ ), with alternations consisting of daily changing the relevant test material from a germinator set at $30^{\circ} \mathrm{C}$ with light to another germinator set at $20^{\circ} \mathrm{C}$ and lined with aluminum foil to prevent light entry.

Tests were performed in a gerbox using three blotting paper sheets. Four replicates of 50 seeds were tested over a period of 15 days, and the result was expressed as average percentage of normal seedlings.

\subsection{Quantification and separation of unfilled seeds}

2.3.1 Characterization of the physical quality of seeds by $\mathrm{X}$-ray use

Samples were taken from the 2002 seed lot for analysis by a Faxitron 43855X X-ray system using the energy range 10, 20, 30 and $40 \mathrm{Kv}$ and exposure times 30 , 45 and 60 seconds. For image acquisition, a Kodak MR 2000 screen film was used $(18$ x $24 \mathrm{~cm})$.

According to the internal morphology viewed in each radiograph, seeds were divided into three categories: filled seeds (with a well developed embryo filling the entire inside of the achene), malformed seeds (with the embryo only partially filling the achene), and unfilled seeds (with no embryo). Filled and malformed seeds are referred to as embryonic seeds.

Cerne, Lavras, v. 17, n. 3, p. 321-326, jul./set. 2011 


\subsubsection{Seed germination after the X-ray test}

Seeds identified in radiographs as being unfilled, filled and malformed were all taken to germinate. The germination test followed the same methodology as in the initial assessment of seed lots.

\subsubsection{Seed separation}

For separation of embryonic seeds, a South Dakota De Leo blower was used. Openings were defined in the scale of the blower, in such way that openings below the 2.0 marking did not produce a light fraction while openings above the 6.0 marking removed all seeds to the light fraction.

The blower was regulated at opening settings 2.0, 3.0, 4.0, 5.0 and 6.0 and at ventilation times 30 and 60 seconds. Each treatment consisted of four replicates with two grams of seeds. After fractions were separated, the heavy fraction was manually purged of residual inert material and seeds were then weighed and the weight was converted into percentage of the original weight. The percentage of embryonic seeds in the heavy fraction was quantified by X-ray analysis, with 50 seeds from each heavy fraction being analyzed. For the 2002 seed lot, the number of seeds per kilogram of original lot and best separation treatment was determined, using eight samples of 100 seeds weighed on a scale accurate to $0.0001 \mathrm{~g}$.

Data were analyzed by SISVAR statistical software with a probability of $\mathrm{F}<1 \%$ and with means being compared by the Tukey test at the 0.05 level.

\subsection{Determination of imbibition curves}

For imbibition curves, the 2002 seed lot was used. Original moisture content was determined according to the methodology mentioned earlier. Curves were based on two replicates using $0.05 \mathrm{~g}$ of seeds placed in a gerbox containing three blotting paper sheets as substrate, saturated with distilled water. Samples were placed in Mangelsforffii germinators regulated at the temperature of $30^{\circ} \mathrm{C}$ with continuous light and temperatures of $20^{\circ}-30^{\circ} \mathrm{C}$ and $30^{\circ}-20^{\circ} \mathrm{C}$ (10 hours of light at $30^{\circ} \mathrm{C}$ followed by 14 hours of dark at $20^{\circ} \mathrm{C}$ ). Every three hours, the seeds were removed from the gerboxes and weighed on a scale accurate to $0.0001 \mathrm{~g}$ for detection of imbibition phases I, II and III.

\section{RESULTS AND DISCUSSION}

\subsection{Characterization of seed lots}

Original moisture, purity and germination characteristics of the relevant seed lots are provided in Table 1. Equilibrium moisture content ranged from
$7.0 \%$ to $9.5 \%$. Both lots showed low germination values, confirming previous reports, including a study by Velten and Garcia (2005), in which the maximum germination rate computed in seeds of this species was $51 \%$.

Table 1 - Moisture, purity and germination (normal seedlings) of seed lots of Eremanthus incanus used in the X-ray and seed separation experiments.

Tabela 1 - Umidade, pureza e germinação (plântulas normais) dos lotes de sementes de Eremanthus incanus utilizados nos experimentos de raios $X$ e separação de sementes.

\begin{tabular}{lccc}
\hline Lot & Moisture (\%) & Purity (\%) & Germination (\%) \\
\hline 2001 & 9.5 & 38.26 & 64 \\
2002 & 7.0 & 84.86 & 41 \\
\hline
\end{tabular}

\subsection{Characterization of the physical quality of seeds by $\mathrm{X}$-ray use}

The radiograph images obtained from using the $30 \mathrm{KV}$ energy setting allowed better viewing of the internal structures of seeds, and the exposure times 45 and 60 seconds favored fineness of detail, allowing identification of the three proposed seed categories. The variation in visibility and contrast using different KV energy settings is explainable, since the greater the energy contained in the ray stream the greater its penetrating power (BONZANINI NETO, 2003). The interpretation of radiographs followed the proposal described by Simak (1991), in which areas with low density tissues (or with no tissues) are more easily transposed by X-rays, causing the film to become darker.

The seed type obtained by the X-ray test (filled, malformed and unfilled) directly influenced germination. Table 2 shows that filled seeds reached $50 \%$ germination (considering normal seedlings), denoting considerable improvement to quality in comparison to the condition of original seed lots, subject as they were to the influence of the unfilled and malformed fraction (Table 1). The performance pattern of malformed seeds was noted to be poorer than that of filled seeds.

Within the 'malformed' seed category, there probably were different stages of embryo development, since some seeds generated normal seedlings. This is a common occurrence in forest species and is certainly due to initial dissimilarities in development, as reported by Carvalho and Nakagawa (1988). Machado and Cícero (2003) in a study about the morphology of Lithraea molleoides, and Melo et al (2009) in a study with seeds of Lyhnophora pinaster, a species of family Asteraceae,

Cerne, Lavras, v. 17, n. 3, p. 321-326, jul./set. 2011 
Table 2 - Germination test results (in percentage) for filled, malformed and unfilled seeds of Eremanthus incanus.

Tabela 2 - Resultados (em porcentagem), do teste de germinação das sementes de Eremanthus incanus cheias, mal formadas $e$ vazias.

\begin{tabular}{lccc}
\hline \multirow{2}{*}{ Criteria } & \multicolumn{3}{c}{ Seeds condition } \\
\cline { 2 - 4 } & Filled & Malformed & Unfilled \\
\hline Radicle protrusion & $80 \mathrm{a}$ & $40 \mathrm{~b}$ & $0 \mathrm{c}$ \\
Normal seedling & $50 \mathrm{a}$ & $7 \mathrm{~b}$ & $0 \mathrm{~b}$ \\
\hline
\end{tabular}

Means followed by the same letter in a row are similar by the Tukey test at the 5\% probability level.

obtained results that demonstrate these maturation dissimilarities, quantifiable by using the $\mathrm{X}$-ray technique.

\subsubsection{Seed separation in the blower}

Time 30 seconds was found more effective than time 60 seconds, keeping more seeds in the heavy fraction on account of less ventilation time. The 2002 lot showed greater heavy fraction weight than the 2001 lot (Table 3), this pattern possibly being the result of that lot having greater original purity (Table 1).

Table 3 - Percentage of the heavy fraction weight for two seed lots of Eremanthus incanus, after passing through a South Dakota seed blower with opening settings 2, 3, 4, 5 and 6 .

Tabela 3 - Porcentagem de peso da fração pesada para sementes de Eremanthus incanus, de dois lotes, após passagem pelo soprador de sementes tipo South Dakota ajustado para as aberturas 2, 3, 4, 5 e 6 .

\begin{tabular}{lcc}
\hline \multirow{2}{*}{ Opening } & \multicolumn{2}{c}{ Heavy fraction (\%) } \\
\cline { 2 - 3 } & $2002 \mathrm{Lot}$ & $2001 \mathrm{Lot}$ \\
\hline 2 & $75.90 \mathrm{aA}$ & $33.79 \mathrm{bA}$ \\
3 & $67.10 \mathrm{aB}$ & $30.67 \mathrm{bB}$ \\
4 & $38.84 \mathrm{aC}$ & $20.32 \mathrm{bC}$ \\
5 & $12.54 \mathrm{aD}$ & $11.81 \mathrm{aD}$ \\
6 & $2.37 \mathrm{bE}$ & $4.38 \mathrm{aE}$ \\
\hline
\end{tabular}

Means followed by the same small letter in a row and capital letter in a column are similar by the Tukey test at the 5\% probability level.

From opening setting 3 (Table 4), no significant increase is observed in the number of embryonic seeds. Original lots showed a $71.25 \%$ rate of embryonic seeds, close to the value found by Davide and Tonetti (2003) based on germination testing (62\%). After passing through the seed blower, the number of embryonic seeds increased to values exceeding $99 \%$.

Cerne, Lavras, v. 17, n. 3, p. 321-326, jul./set. 2011
Table 4 - Mean percentages of embryonic seeds of Eremanthus incanus in the heavy fraction for each opening setting, as observed by the X-ray test.

Tabela 4 - Porcentagens médias de sementes de Eremanthus incanus com embrião, na fração pesada, dentro de cada abertura testada, observado pelo teste de raios $X$.

\begin{tabular}{cc}
\hline Opening & Percentage of embryonic seeds \\
\hline 2 & $92.75 \mathrm{~b}$ \\
3 & $98.50 \mathrm{a}$ \\
4 & $98.25 \mathrm{a}$ \\
5 & $99.62 \mathrm{a}$ \\
6 & $99.31 \mathrm{a}$ \\
\hline
\end{tabular}

Means followed by the same letter in a column do not differ by the Tukey test at the $5 \%$ probability level.

Separation in the Dakota blower resulted in a reduction from 2,680,000 seeds to 1,666,600 seeds per kilogram. This drop in the number of seeds per unit of weight $(\mathrm{Kg})$ demonstrates that blown seed lots did concentrate larger, denser seeds, indicating improvement to lot quality. According to Carvalho and Nakagawa (1988), denser seeds are the result of better nurturing, which makes them surpass late formed seeds in regard to density.

\subsection{Imbibition curve}

Imbibition curves followed the three-phased pattern proposed by Bewley and Black (1994). The initial water content in seeds was 6.26\%. Curve results (Figure 1) showed a fast imbibition phase I (up to six hours) for the three conditions being tested, with the water content in seeds reaching around $45 \%$. Imbibition phase II came next, extending for up to 72 hours, with the water content in seeds reaching around $56 \%$. Water contents found in each phase suggest that these seeds have cotyledonal storage tissue, the reason being that, according to Coperland and McDonald (1999), at the end of phase I the water content in seeds with this type of storage tissue should reach $35 \%$ to $40 \%$, against $50 \%$ to $60 \%$ at the end of phase II.

The proportion of time elapsed between the first two phases agrees with descriptions by Bewley (1997) in that, usually, phase II lasts up to ten times longer than phase I in undormant seeds. Typically during this phase cell elongation is all that takes place (BEWLEY; BLACK, 1994; BEWLEY, 1997).

Temperatures tested did not promote significant differences until the end of phase II. Differences were 


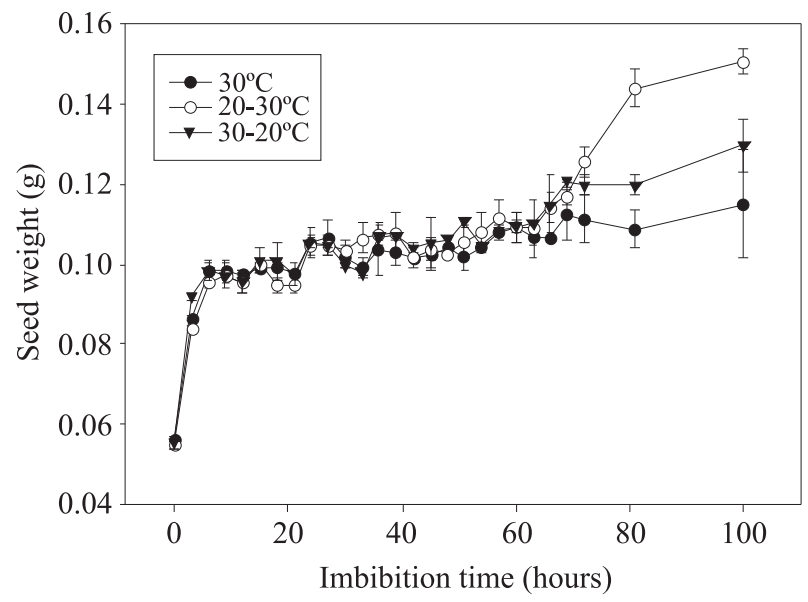

Figure 1 - Imbibition curves for seeds of Eremanthus incanus, under a temperature of $30^{\circ} \mathrm{C}$ and constant light and under alternate temperatures of $20^{\circ}-30^{\circ} \mathrm{C}$ and $30^{\circ}-20^{\circ} \mathrm{C}$ with 10 hours of light and 14 of dark.

Figura 1 - Curvas de embebição das sementes de Eremanthus incanus, sob temperatura de $30^{\circ} \mathrm{C}$ e luz constante e temperatura alternada de $20-30^{\circ} \mathrm{C}$ e $30-20^{\circ} \mathrm{C}$ com 10 horas de luz e 14 de escuro.

only noted after radicle protrusion, which marks the start of phase III (about 72 hours). According to Bewley (1997), phase III is marked by radicle growth resumption and involves both elongation processes and cell division.

From then on, alternate temperatures of $20^{\circ}-30^{\circ} \mathrm{C}$ with 10 hours of light were found to promote an increase in seed weight, indicating faster growth of essential seedling structures (Figure 1), which suggests that alternate temperatures of $20^{\circ}-30^{\circ} \mathrm{C}$ could favor the establishment of field seedlings.

\section{CONCLUSIONS}

The use of X-rays is viable for assessing physical quality in seeds of Eremanthus incanus, particularly the procedure $30 \mathrm{KV}$ for 45 seconds.

The use of a South Dakota blower regulated at the 3.0 opening setting for 30 seconds is effective in separating unfilled seeds from seed lots of Eremanthus incanus.

Seeds of Eremanthus incanus follow a three-phased pattern of imbibition during germination, to be completed in 72 hours. Alternate temperatures of $20^{\circ}-30^{\circ} \mathrm{C}$ with 10 daily hours of light was found to favor initial growth of seedlings.

\section{ACKNOWLEDGEMENTS}

The authors wish to thank the Research Aid Foundation of Minas Gerais State (FAPEMIG) for providing financial support; the Center for Excellence in Riparian Forests (CEMAC); and the Environment Ministry (MMA) for gathering the seeds used in this work.

\section{REFERENCES}

BEWLEY, J. D. Seed germination and dormancy. The Plant Cell, Rockville, v. 9, n. 7, p. 1055-1066, July 1997.

BEWLEY, J. D.; BLACK, M. Seeds: physiology of development and germination. 2. ed. New York: Plenum, 1994. 445 p.

BONZANINI NETO, P. Histórico sobre os raios-x.

Disponível em: <http://www.dominiobucal.com.br/histrx. htm>. Acesso em: 29 maio 2003.

BRASIL. Ministério da agricultura. Regras para análise de sementes. Brasília, 1992. 365 p.

CARVALHO, M. M. de; NAKAGAWA, J. Sementes: ciência tecnologia e produção. 3. ed. Campinas: Fundação Cargill, 1988. 424 p.

COPERLAND, L. O.; MCDONALD, M. B. Principles of seed science and technology. London: Kluwer Academic, 1999. 409 p.

CORREA, M. P. Dicionário das plantas úteis do Brasil e das exóticas cultivadas. Rio de Janeiro: Ministério da Agricultura, Indústria e Comércio, 1984. v. 5, 687 p.

DAVIDE, A. C.; TONETTI, O. A. O. Germinação de sementes de Eremanthus incanus (Candeião) sob dois regimes de temperatura e luz. Informativo ABRATES, Londrina, v. 13, n. 3, p. 349, set. 2003.

\section{FUNDAÇÃO CENTRO TECNOLÓGICO DE MINAS}

GERAIS. Ecofisiologia da candeia. Belo Horizonte, 1994. 104 p.

INTERNATIONAL SEED TESTING ASSOCIATION. International rules for seed testing. Zurich, 1993. 363 p.

MACHADO, C. F.; CÍCERO, S. M. ‘Aroeira-branca’ (Lithraea molleoides (Vell. Engl. - Anacardiaceae) seed quality evaluation by the X-ray test. Scientia Agrícola, Piracicaba, v. 60, n. 2, p. 393-397, abr./jun. 2003.

Cerne, Lavras, v. 17, n. 3, p. 321-326, jul./set. 2011 
MELO, P. R. B. de; OLIVEIRA, J. A.; CARVALHO, M. L. M. de; GUIMARÃES, R. M.; CARVALHO, B. de O. Aplicação do teste de raios $\mathrm{X}$ no estudo da morfologia interna e da qualidade fisiológica de aquênios de arnica (Lychnophora pinaster Mart.). Revista Brasileira de Sementes, Brasília, v. 31, n. 2, p. 146-154, 2009.

NÚCLEO DE ESTUDOS EM MANEJO FLORESTAL. Sistema de manejo para a candeia (Eremanthus erythropappus e Eremanthus incanus). Disponível em: <http:// www.nucleoestudo.ufla.br/nemaf>. Acesso em: 1 out. 2003.

SEED NEWS. Avaliação da qualidade de sementes. Pelotas, 2001. Diponível em: <http:/www.seednews.inf.br/português/ seed53/artigocapa53.html>. Acesso em: 10 jun. 2003.
SIMAK, M. Testing of forest tree and shrub seeds by x-radiography. In: INTERNATIONAL SEED TESTING ASSOCIATION. Tree and shrub seed handbook. Zurich, 1991.

TONETTI, O. A. O.; DAVIDE, A. C.; SILVA, E. A. A. da. Qualidade física e fisiológica de sementes de Erementhus erythropappus (DC.) Mac. Leish. Revista Brasileira de Sementes, Brasília, v. 28, n. 1, p. 114-121, 2006.

VELTEN, S. B.; GARCIA, Q. S. Efeitos da luz e da temperatuda na germinação de sementes de Eremanthus (Asteraceae), ocorrentes na Serra do Cipó, MG, Brasil. Acta Botânica Brasileira, São Paulo, v. 19, n. 4, p. 753-761, 2005.

Cerne, Lavras, v. 17, n. 3, p. 321-326, jul./set. 2011 